\title{
A high-resolution 43-year atmospheric hindcast for South America generated with the MPI regional model
}

\author{
Gabriel Silvestri · Carolina Vera · Daniela Jacob • \\ Susanne Pfeifer · Claas Teichmann
}

Received: 30 October 2007 / Accepted: 13 May 2008/Published online: 3 June 2008

(C) The Author(s) 2008

\begin{abstract}
An evaluation of the present-day climate in South America simulated by the MPI atmospheric limited area model, REMO, is made. The model dataset was generated by dynamical downscaling from the ECMWFERA40 reanalysis and compared to in-situ observations. The model is able to reproduce the low-level summer monsoon circulation but it has some deficiencies in representing the South American Low-Level Jet structure. At upper levels, summer circulation features like the Bolivian High and the associated subtropical jet are well simulated by the model. Sea-level pressure fields are in general well represented by REMO. The model exhibits reasonable skill in representing the general features of the mean seasonal cycle of precipitation. Nevertheless, there is a systematic overestimation of precipitation in both tropical and subtropical regions. Differences between observed and modeled temperature are smaller than $1.5^{\circ} \mathrm{C}$ over most of the continent, excepting during spring when those differences are quite large. Results also show that the dynamical downscaling performed using REMO introduces some enhancement of the global reanalysis especially in temperature at the tropical regions during the warm season and in precipitation in both the subtropics and extratropics. It is then concluded that REMO can be a useful tool for regional downscaling of global simulations of present and future climates.
\end{abstract}

G. Silvestri $(\bowtie) \cdot$ C. Vera

CIMA/CONICET, University of Buenos Aires, Buenos Aires,

Argentina

e-mail: gabriels@cima.fcen.uba.ar

D. Jacob $\cdot$ S. Pfeifer $\cdot$ C. Teichmann

Max Planck Institute, Hamburg, Germany
Keywords South American climate . Regional model validation - ERA40 downscaling . REMO model $\cdot$ Atmospheric hindcast

\section{Introduction}

With the emergence of human-induced climate change as one of the most important scientific problems impacting society, regional projections of climate change are urgently required. Recently, the availability of the "WCRP CMIP3 multi-model dataset" (PCMDI, http://www-pcmdi.llnl.gov/ ipcc/about_ipcc.php) has provided an unprecedented data base for climate change assessments. Recent publications show that current global climate simulations can reproduce relatively well the basic features of the general circulation (e.g., Randall et al. 2007). Nevertheless, their performance deteriorates when looking at finer temporal and spatial scales which are needed for many impact assessment studies. Regional models of high resolution can be a more efficient tool to represent the regional climate features and to study their possible evolution in the next decades, particularly over regions with complex topography (e.g., Giorgi et al. 2004).

The South American geography is dominated by the Andes Mountains, a very narrow orographic system spreading along the western continent with heights that reach $6,000 \mathrm{~m}$ in subtropical latitudes. In addition, the Brazilian plateau, covering most of eastern Brazil but with heights lower than the Andes is another important topographic structure in the continent. Both mountainous systems produce distinctive features in the South American climate, particularly at low levels. The presence of a low-level jet like structure along the eastern slopes of the central Andes in the mean wind field and its variability, 
as well as the existence of a region of maximum frequency of winter cyclogenesis over eastern South America, are examples of the orography influence on continental climate (e.g., Vera et al. 2006a, b and references therein).

In general, global circulation models have difficulties to represent the complexity of South American topography. Most of the models have a resolution larger than $1^{\circ}$ (e. g., Dai 2006) producing a smoothed topography that can affect the representation of climatic local conditions. Simulations with different regional models mostly performed on seasonal scales have been done to represent the mean and variability conditions of the South American climate (Berbery and Collini 2000; Seth and Rojas 2003; Rojas and Seth 2003; Misra et al. 2003; Seth et al. 2004; Solman et al. 2007, among others). Seth et al. (2007) examined climatological integrations for South America with a regional climate model using a continental scale domain nested in both reanalysis data and multiple realizations of an atmospheric general circulation model. They conclude that in regions where remote influences are strong and the global model performs well it is difficult for the regional model to improve the large scale climatological features, indeed the regional model may degrade the simulation. Where remote forcing is weak and local processes dominate, there is some potential for the regional model to add value.

Recently, the Max-Planck Institute Regional Model (REMO) has been used to perform climate simulations over different regions of the world with promising results (e.g., Birnbaum 2003; Aldrian et al. 2004; Sotillo et al. 2005; Jacob et al. 2007). The present paper is focused on the atmospheric hindcast performed using the REMO model over South America by means of dynamical downscaling from the ECMWF-ERA40 reanalysis, covering a 43-year period (1958-2000). Special attention is given to exhaustively assess the REMO ability in reproducing the basic observed characteristics of the South American climate as well as to evaluate improvements introduced by the hindcast on already existing climate reanalysis data. The analysis is mainly focused on the validation of monthly mean temperature, precipitation and circulation for the period 1979-2000. The purpose of the assessment is to evaluate if REMO is an appropriate tool for dynamical downscaling of low-resolution global climate models over South America for climate change scenario and for seasonal prediction.

Data and the model are described in Sect. 2. The comparisons between observed, reanalyzed and modeled circulation, temperature and precipitation fields over South America are discussed in Sects. 3 and 4. The main conclusions are summarized in Sect. 5.

\section{Model, data and methodology}

\subsection{Model}

The regional climate model REMO (Jacob 2001; Jacob et al. 2001) is a three-dimensional hydrostatic atmospheric model. It has been developed at the Max-PlanckInstitute for Meteorology in the context of the Baltic Sea Experiment (BALTEX). REMO is based on the EM/DM model (the former numerical weather prediction model of the German weather service DWD) and uses the physical parameterizations of the MPI-M global model ECHAM4. A mass flux convection scheme (Tiedtke 1989; Nordeng 1994) is used to parameterize cumulus convection, while soil related processes are calculated from diffusion equations solved in five different layers covering the uppermost $10 \mathrm{~m}$ of the soil (Dümenil and Todini 1992).

In the simulation used in this study, the prognostic variables temperature, pressure, the two wind components and humidity are prescribed at the lateral boundaries according to Davies (1976), using ECMWF-ERA40 reanalysis data. They are relaxed in a boundary zone of eight grid boxes, where the influence of the reanalysis data decreases from the boundary to the center of the model domain. The initial meteorological fields and the sea surface temperature at the lower boundary are also taken from the ECMWF-ERA40 data. The REMO model has been run in the climate mode. The simulation started on 1 st of January 1958 and ran continuously until 31st of December 2000. The model resolution is $0.5^{\circ} \times 0.5^{\circ}$ and the domain covers the whole South American continent. The model domain and orography are shown in Fig. 1.

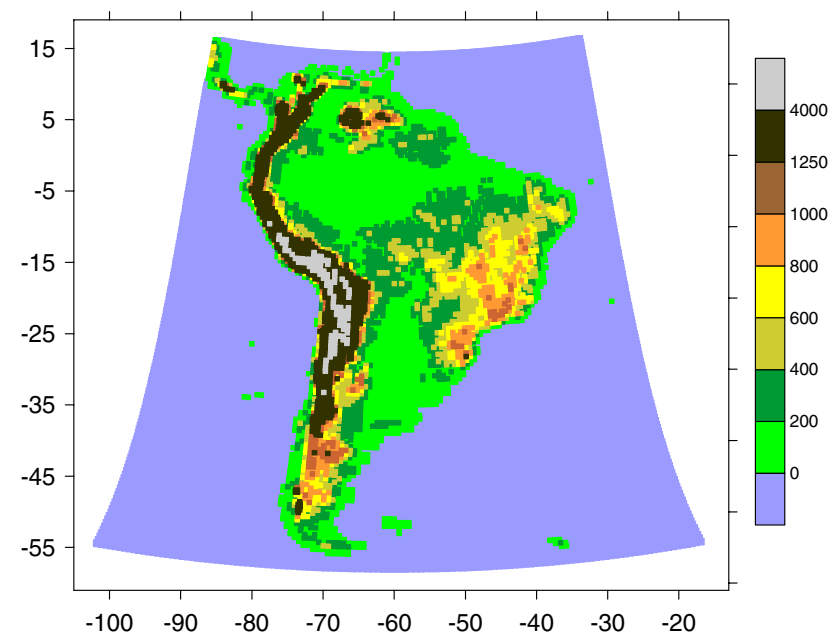

Fig. 1 Model domain and orography. Scale in meters 


\subsection{Data and methodology}

The observed monthly mean fields of wind at 850 and $200 \mathrm{hPa}$ were taken from ECMWF-ERA40. Fields are available on a $1.125^{\circ} \times \sim 1.125^{\circ}$ global grid (reduced n80 Gaussian latitude/longitude). Monthly mean data of precipitation, temperature and sea level pressure (SLP) were obtained from the National Meteorological Service of Argentina and from the National Center for Atmospheric Research (NCAR) database. More than 1,200 stations are available in South America for the period 1979-2000. However, most of them have many missing data. Thus, only the stations with at least 10 years of data were considered. In addition, to avoid possible deficiencies associated with the nearness to the limit of the model domain, stations located near to the border were not considered either.

Temperature, SLP and precipitation data were compared to REMO values at the station locations using the methodology described in Kjellström et al. (2007). The observation at one single station was compared to those from at least 4-9 model grid boxes. A height correction is applied to the model temperature data in order to account for height differences between station and model grid-box, considering a lapse rate of $0.65^{\circ} \mathrm{C} / 100 \mathrm{~m}$. Due to model limitations in representing accurately the topography, large altitude differences exist between some stations located right over the Andes Mountains and the corresponding grid points. Therefore, those grid points that have an altitudinal difference with the corresponding station exceeding $1,000 \mathrm{~m}$ as well as those stations above 2,000 $\mathrm{m}$ have been excluded from the analysis. Only 163 stations are available once the criteria above mentioned were applied (Fig. 2).

Due to very sparse distribution of the available station data, the fields of monthly precipitation from the Climate Prediction Center (CPC) merged analysis of precipitation (Xie and Arkin 1997) dataset were also used.

Hereafter, the seasons mentioned correspond to those for the southern hemisphere. In that sense, the fields for January, April, July, and October shown in the paper should be considered as representative of summer, fall, winter and spring, respectively.

\section{Observed and REMO circulation}

During summer, the low-level circulation in South America exhibits distinctive features (Fig. 3a; Virji 1981; Lenters and Cook 1995; Wang and Paegle 1996; Zhou and Lau 1998; Vera et al. 2006a, b). Trade winds enter the continent at low latitudes from the tropical Atlantic Ocean, that are channeled southward by the Andes reaching subtropical latitudes. A poleward low-level jet (LLJ) structure is evident along the east slopes of the Andes with maximum mean

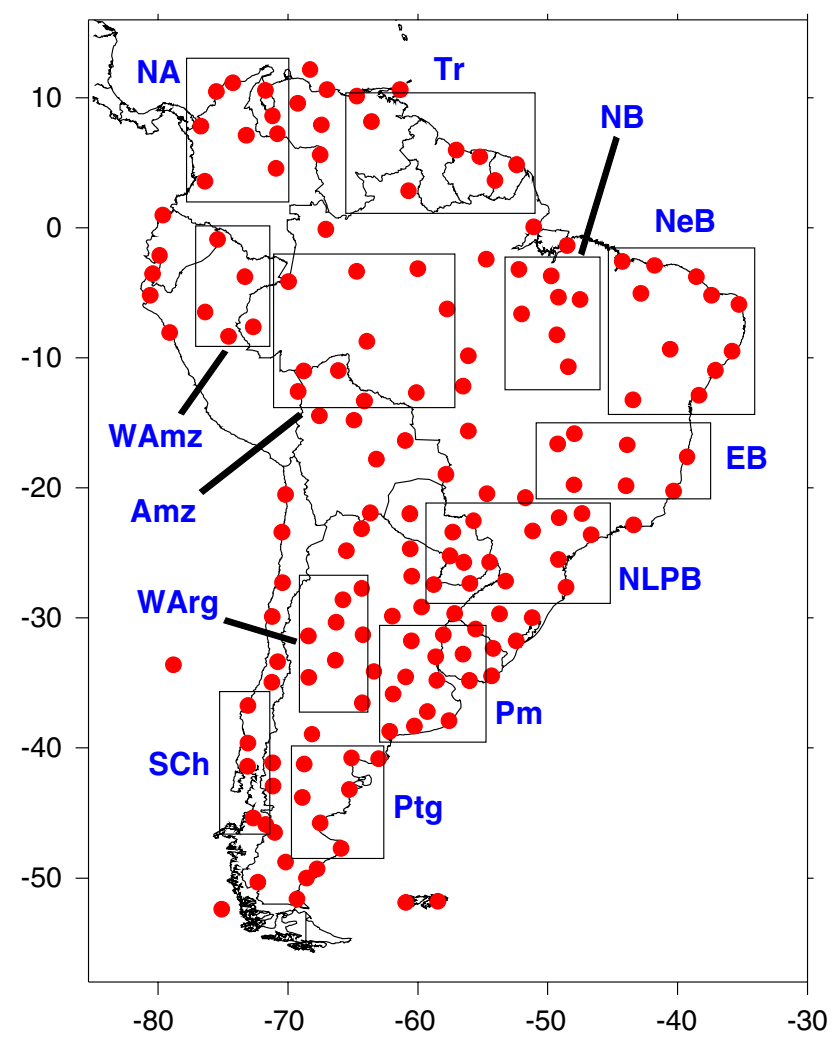

Fig. 2 Locations of the stations and the 12 sub-regions considered in the study. NA, Northern Andes; $T r$, Tropical; WAmz, Western Amazonia; Amz, Amazonia; NB, Northern Brazil; NeB, Northeastern Brazil; $E B$, Eastern Brazil; $N L P B$, Northern La Plata basin; Pm, Pampa; WArg, Western Argentina; Ptg, Patagonia; SCh, Southern Chile

winds between 10 and $20^{\circ} \mathrm{S}$. At tropical and subtropical latitudes, the Andes Mountains act as a barrier to the lowlevel atmospheric flow from the Pacific Ocean. Southward of $45^{\circ} \mathrm{S}$ the mountains are lower and the flow over the continent is dominated by the westerlies from the Pacific. In winter (Fig. 3b), trade winds penetrate the continent more to the south from its respective position in summer. The LLJ is as intense as in summer although located southward. At high latitudes, the circulation is dominated by the westerlies but its intensity is lower than in summer.

Figure $3 \mathrm{c}, \mathrm{d}$ show that the model is able to represent the basic structure of the low-level circulation over South America, including the anticyclonic gyre over the tropical portion of the continent as well as the location and intensity of the westerlies over the southern tip. However, the model is deficient in representing both the elongated structure and intensity associated with the LLJ. Furthermore, the summer poleward flow simulated along the eastern coast (slope of the Andes) is much weaker (stronger) than observed.

The upper-level circulation observed during summer over South America is displayed in Fig. 4a. It is characterized at the tropical regions by an anticyclonic circulation centered on around $20^{\circ} \mathrm{S}, 70^{\circ} \mathrm{W}$ (the Bolivian high) and a 
Fig. 3 Mean $850 \mathrm{hPa}$ winds in January and July from ECMWF-ERA40 (upper panel) and REMO (lower panel). Wind magnitude is shaded and arrows indicate wind direction. Units are $\mathrm{m} \mathrm{seg}^{-1}$

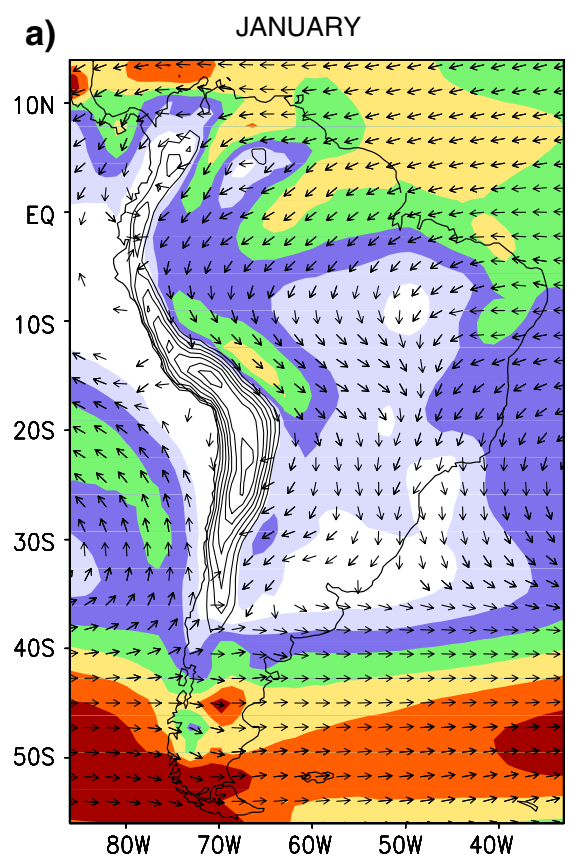

c)

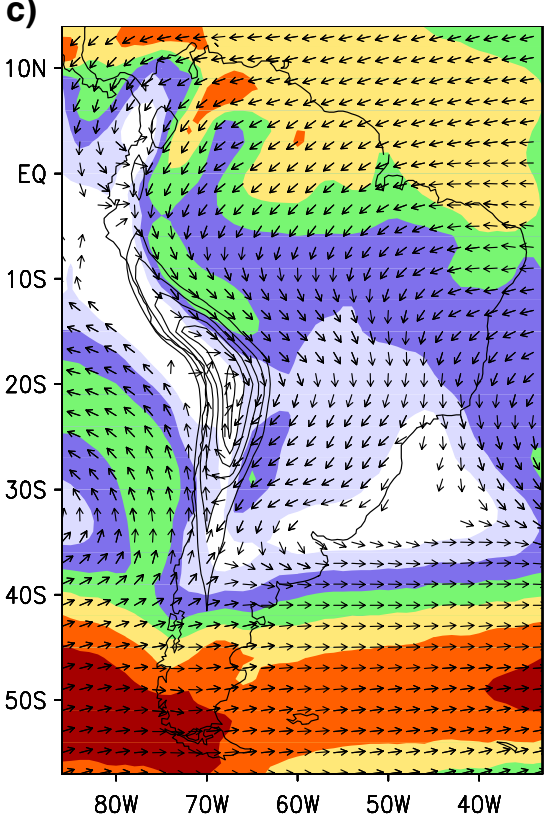

b) JULY

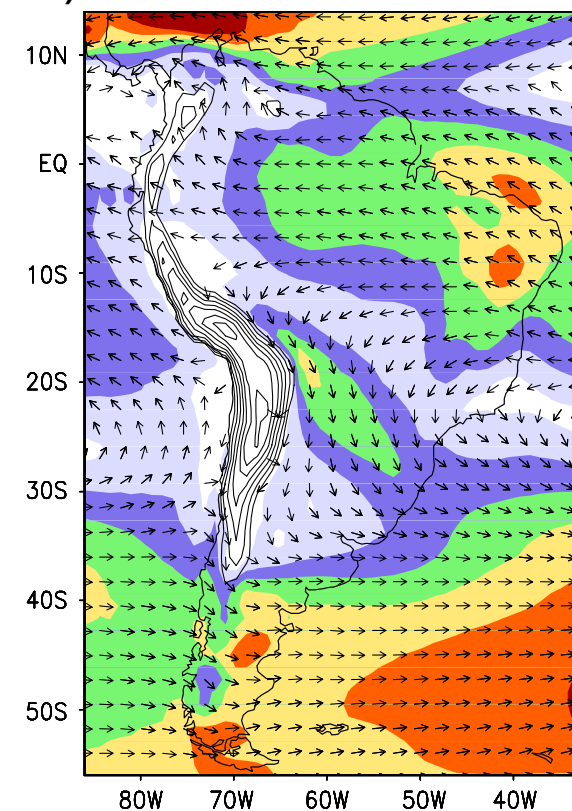

d)

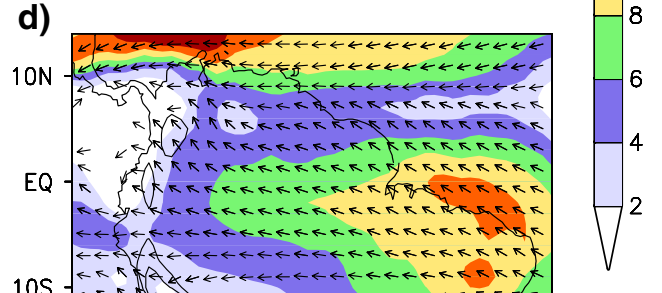

cyclonic circulation (the Nordeste trough) at the Northeast coast, both associated with the diabatic heating release at the Amazon region (e.g., Lenters and Cook 1997; Chen et al. 1999; Vera et al. 2006a). An intensification of westerlies is also observed towards higher latitudes. On the other hand during winter, an equatorward migration of westerlies is evident with maximum intensity at subtropical latitudes, being a regional manifestation of the upper-level subtropical jet (Fig. 4b). Figure 4c, d show that the model is able to reproduce the main summer features associated with the Bolivian High as well the winter intensified westerlies at the subtropical regions.

\section{Observed and REMO precipitation, temperature and SLP}

\subsection{Continental features}

\subsubsection{Precipitation}

The mean seasonal cycle of precipitation in South America calculated from CMAP dataset presents distinctive features. During summer (Fig. 5a), the region of maximum precipitation locates along a northwest-southeast oriented band extended from the Amazon region into the South 
Fig. 4 Mean $200 \mathrm{hPa}$ winds in January and July from ECMWF-ERA40 (upper panel) and REMO (lower panel). Wind magnitude is shaded and arrows indicate wind direction. Units are $\mathrm{m} \mathrm{seg}^{-1}$
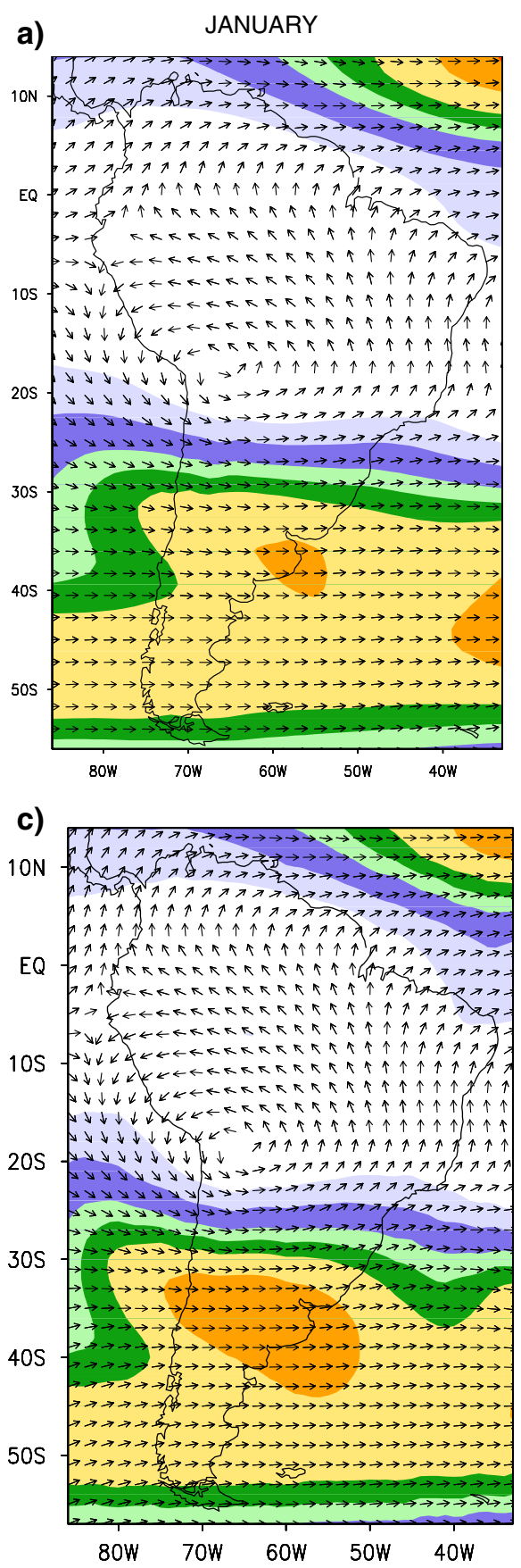

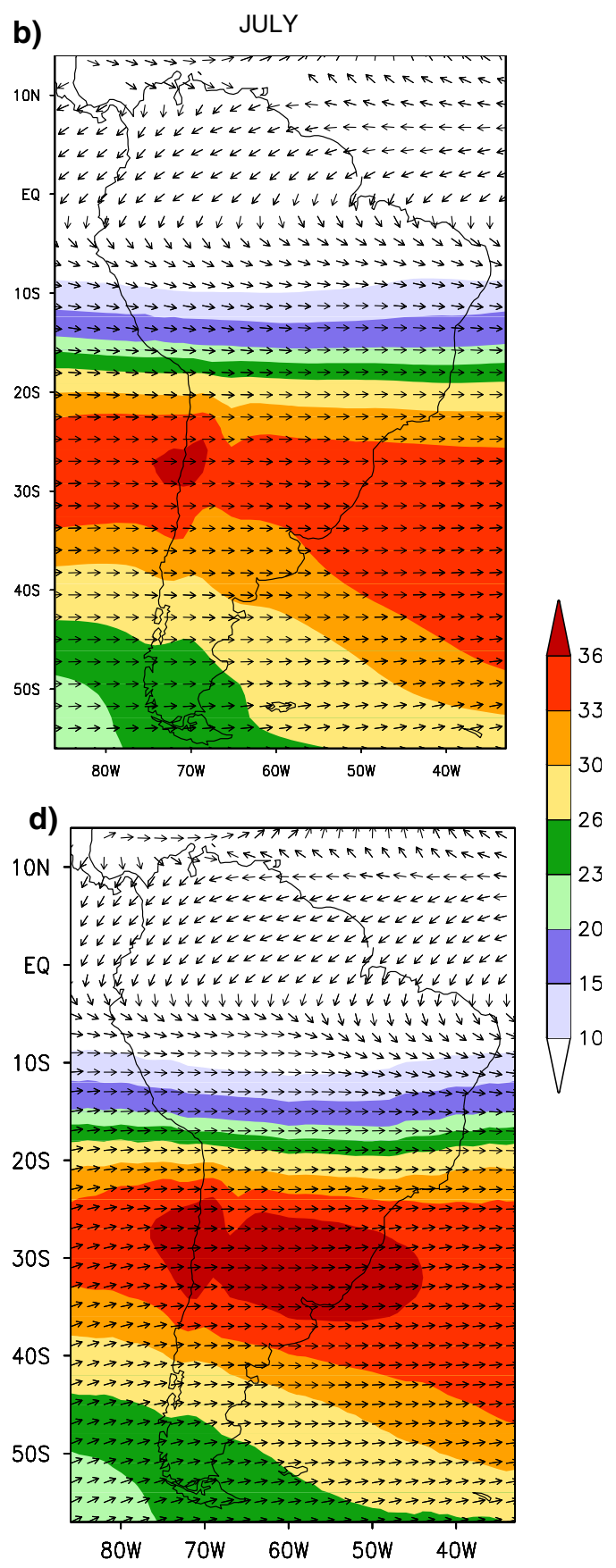

Atlantic Ocean (e.g., Hoffmann 1975; Prohaska 1976). This band of precipitation, known as the South Atlantic convergence zone (SACZ; Kodama 1992; Lenters and Cook 1995; Nogués-Paegle and Mo 1997; Gandú and Silva Días 1998), exhibits considerable variability ranging from diurnal to interdecadal time scales (Vera et al. 2006a, and references therein). During fall (Fig. 5b), tropical convection migrates northwestward while a local maximum of precipitation develops at subtropical latitudes to the east of the Andes Mountains. This regional maximum persists during winter (Fig. 5c), while tropical precipitation is concentrated in the northwestern portion of the continent. During spring (Fig. 5d), convection migrates southeastwards, the rainy season onset occurs over the Amazon region and the SACZ intensification begins.

REMO is able to reproduce the general structure of the mean seasonal cycle of rainfall. In particular the model reproduces reasonably well the characteristics of the SACZ during summer and the winter precipitation maximum in the southeast. Spring is the only season in which the model has deficiencies in accurately reproducing the rainfall behavior. Figure $5 \mathrm{~d}$ shows that a maximum of precipitation 

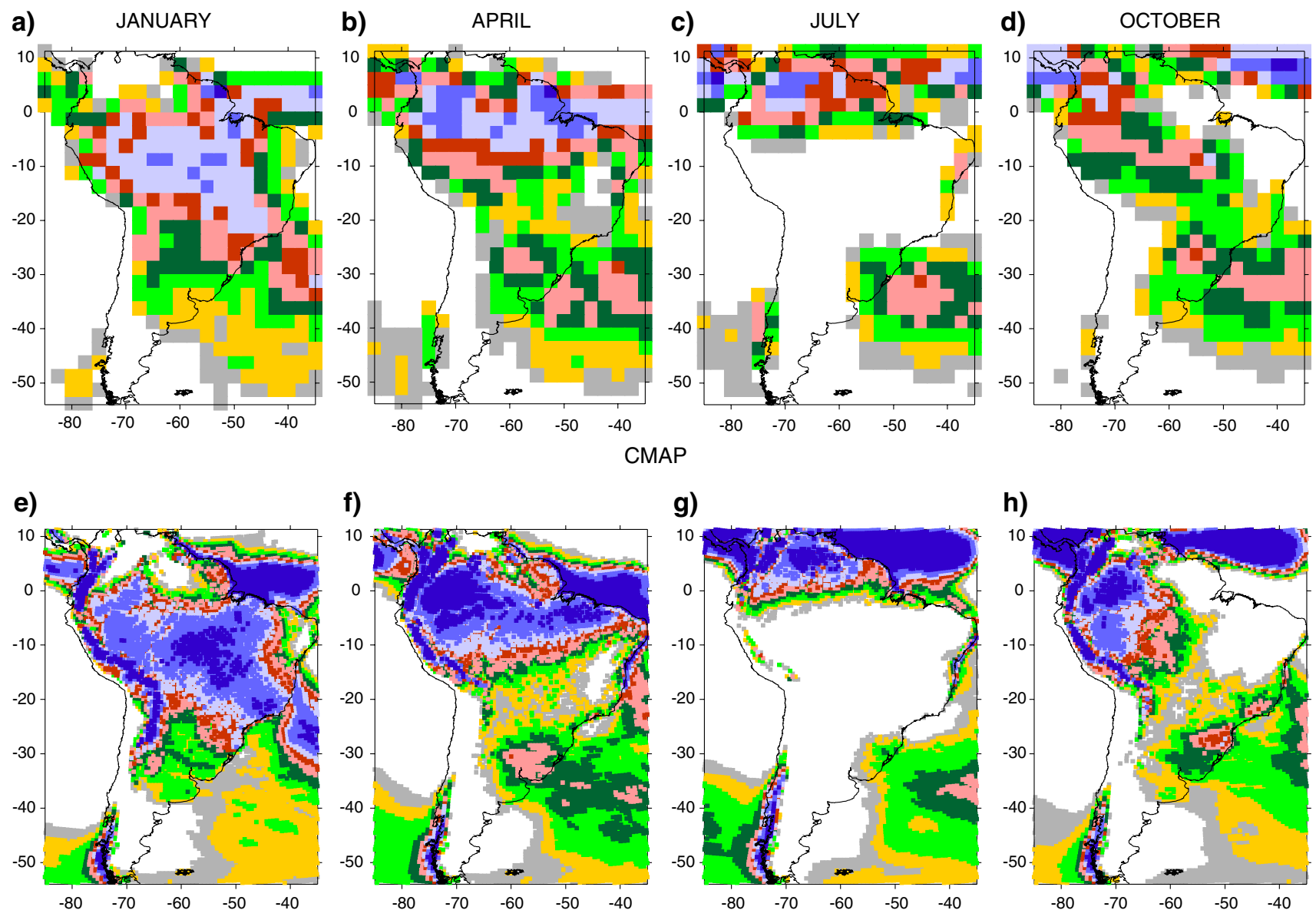

g)

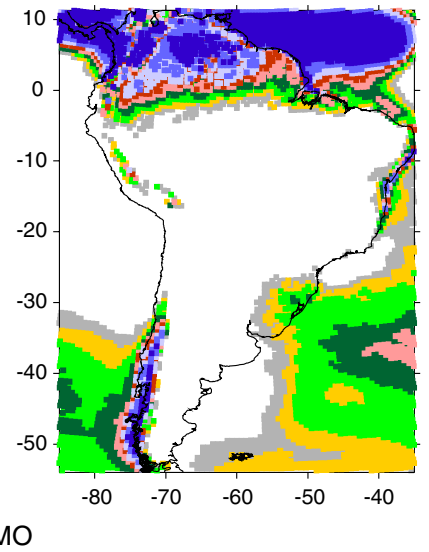

h)

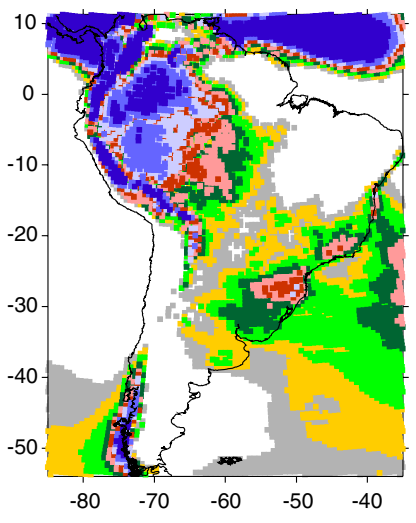

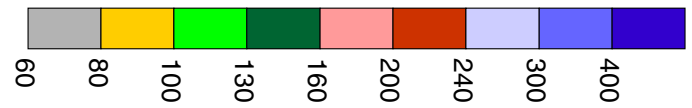

Fig. 5 CMAP (upper panel) and REMO (lower panel) mean precipitation in January, April, July and October. Units are mm month ${ }^{-1}$

over central South America and the structure of the SACZ are already developed. Though the model simulates a precipitation maximum at the tropical regions located too much northwestwards, too little rainfall at the central region, and a spatial pattern over the southeastern region that still resemble that for winter (Fig. 5h).

REMO mean errors in precipitation were quantified as the differences between simulated and observed magnitudes of the rainfall climatological monthly mean for each station and displayed in Fig. 6. It is evident that the model produces more rainfall than observed over most of the continent, especially on the Andes and austral Patagonia with differences that exceed $100 \%$. During summer and fall, simulated values do not exceed in general $50 \%$ from the observed over the central and southeastern region. Nevertheless, REMO winter precipitation is much lower than the observed one on a wide region in tropical and subtropical latitudes (Fig. 6c). This characteristic still persists during spring in the eastern tropical sector (Fig. 6d).
The comparison between global reanalysis and the REMO hindcasted data shows that the dynamical downscaling introduces an improvement in the representation of regional precipitation. The absolute value of the differences REMO minus observed (DIF1) and ERA40 minus observed (DIF2) were calculated and the differences DIF1 minus DIF2 are plotted in Fig. 7. Negative values (red dots) indicate that REMO is out-performing the ERA40 reanalysis. A better performance by REMO is evident over $25^{\circ} \mathrm{S}-40^{\circ} \mathrm{S}$ in summer and over most of the region between $0^{\circ}$ and $40^{\circ} \mathrm{S}$ in winter.

\subsubsection{Temperature}

The ability of the model in representing the temperature mean seasonal cycle in South America is quantified in Fig. 8. Large differences above $4^{\circ} \mathrm{C}$ are evident along the western coast, representing the model warmer conditions than observed. Marine stratocumulus typically develops 
Fig. 6 Precipitation REMO mean error (simulations minus observations). Values are displayed in percentage regarding to the observed magnitudes
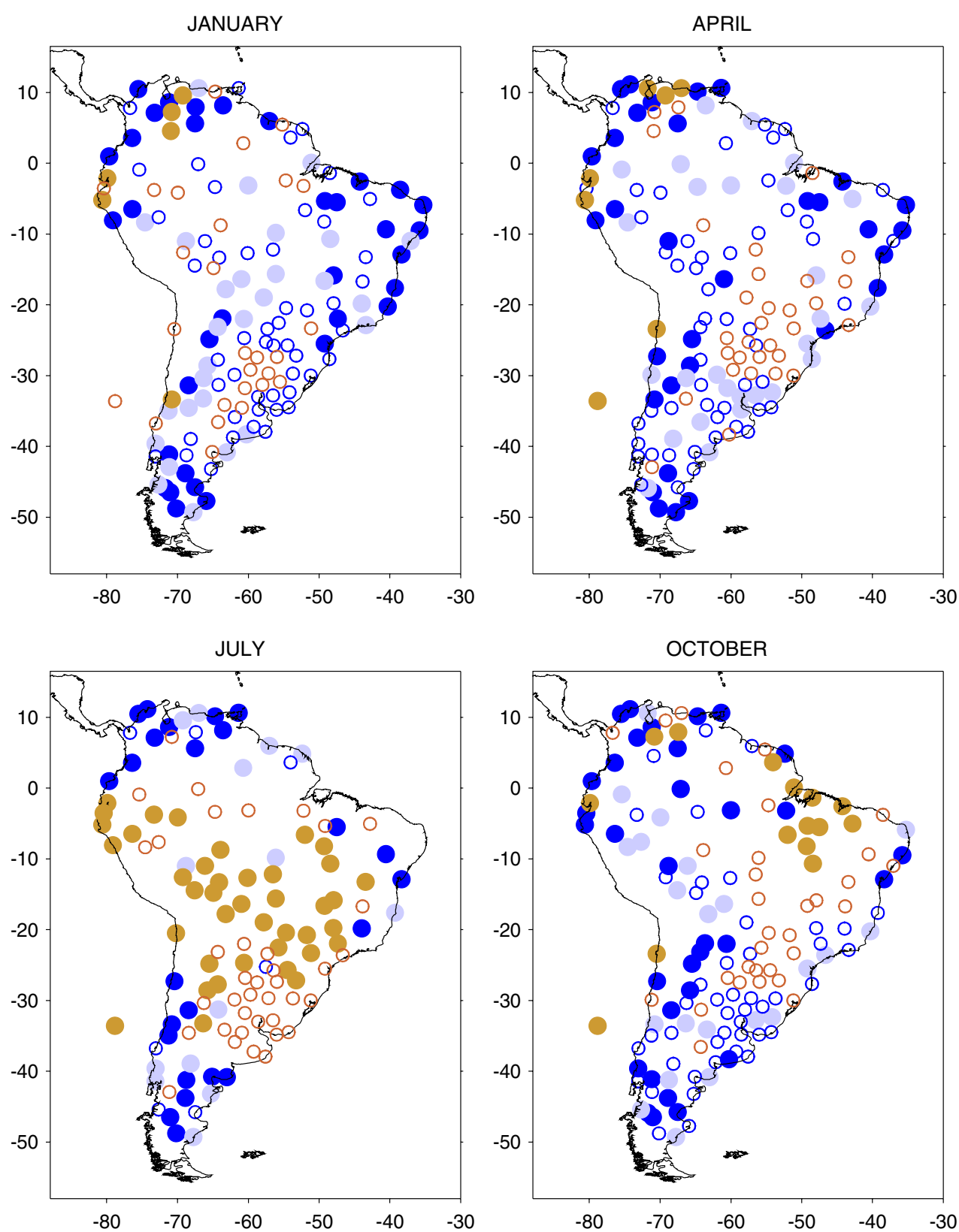

over the southeastern Pacific and has a strong influence on the radiation budget of the region. Such cloud systems are not well represented by some models (e.g., Collins et al. 2006) which seems to be also the case for REMO.

During summer and fall the greatest temperature differences are found between $20^{\circ} \mathrm{S}$ and $40^{\circ} \mathrm{S}$ (Fig. 8a, b) while during winter, positive differences cover most of the continent that exceed $3^{\circ} \mathrm{C}$ in subtropical latitudes to the east of the Andes (Fig. 8c). Moreover, modeled temperatures exceed $4^{\circ} \mathrm{C}$ or more the observed ones over most of the Amazon and northern Brazil during late winter and early spring (Fig. 8d).

The comparison between both REMO and ERA40 differences against in-situ observations shows that the dynamical downscaling performed through REMO introduces a regional improvement of the global reanalysis mainly in the representation of temperature at tropical regions in summer and autumn (Sect. 4.2). 
Fig. 7 Differences between REMO and ERA40 absolute mean errors for precipitation. As in Fig. 6, mean errors are displayed in percentage regarding to the observed magnitudes
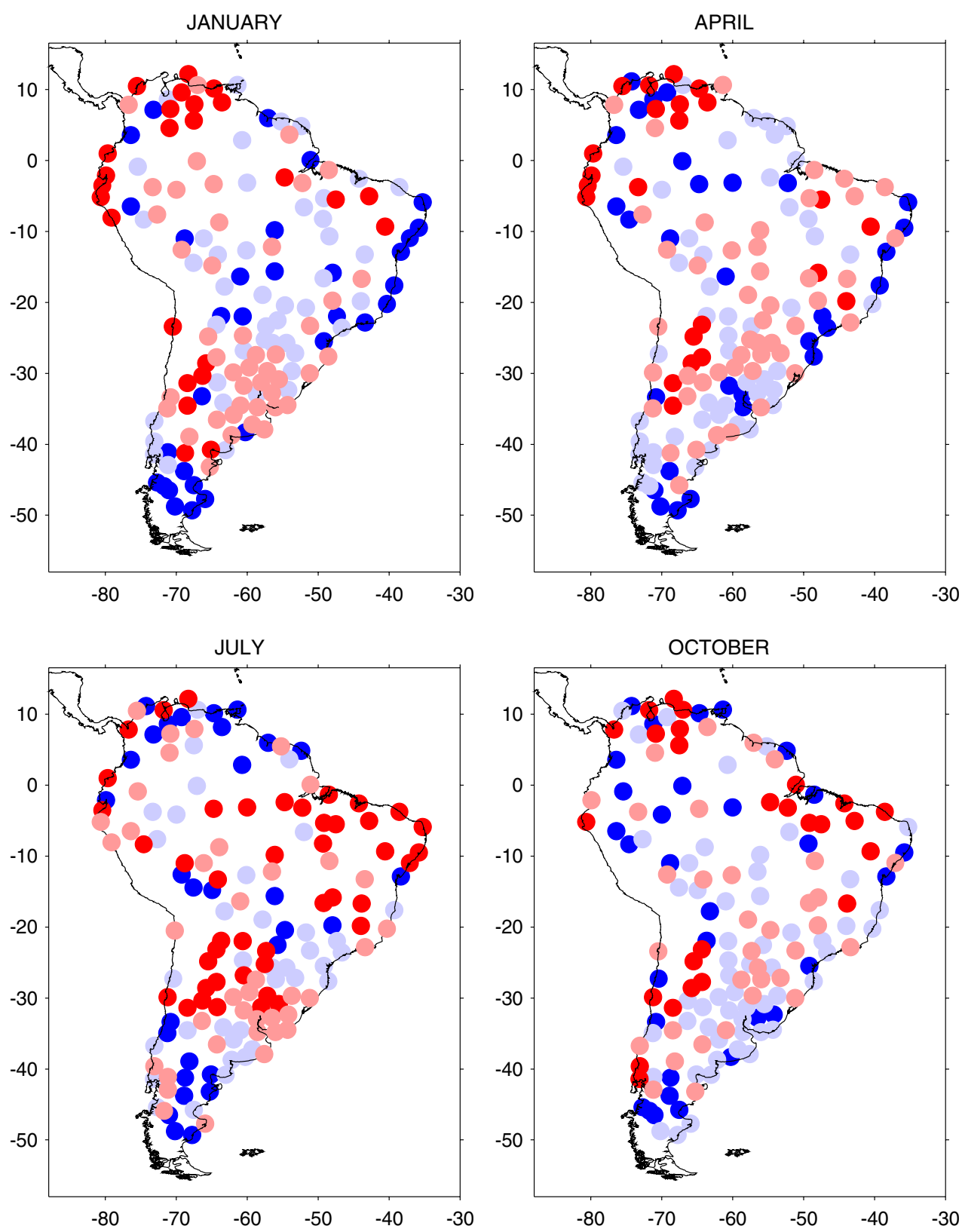

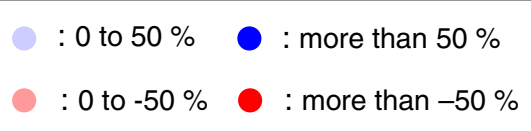

\subsubsection{Sea level pressure}

A quantification of the model skill in reproducing the observed circulation is presented here that complements the analysis performed in Sect. 3. Figure 9 shows the differences in climatological means of SLP between REMO and observations. In summer, autumn and early winter differences are lower than $2 \mathrm{hPa}$ over most of the continent but in points near the Andes mountains there are differences of $4 \mathrm{hPa}$. During that season, the modeled SLP is higher than the observed one on the coast of the Atlantic Ocean to the south of $15^{\circ} \mathrm{S}$. On the contrary, in most of the points located in tropical and subtropical latitudes near the Andes the magnitudes are lower in the model. These characteristics persist during late winter and spring but the magnitude of the differences are increased to the north of $20^{\circ} \mathrm{S}$, especially in the period August-October when they are of $2-4 \mathrm{hPa}$ in the majority of the points. The fact that south of $20^{\circ} \mathrm{S}$, the zonal SLP gradient is stronger in REMO than in observations, might explain the differences in the 
Fig. 8 Temperature REMO mean error (simulations minus observations)
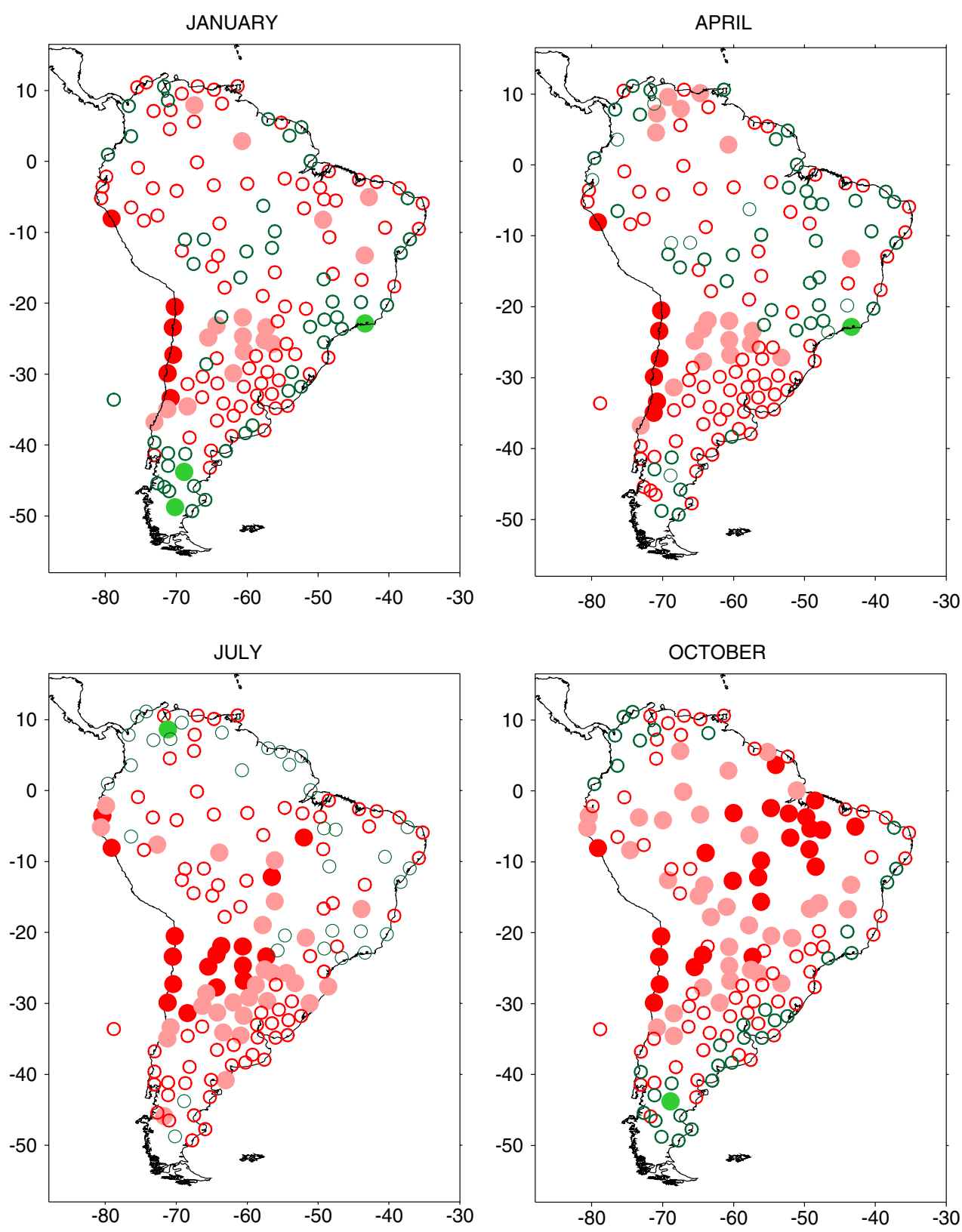

low-level winds found between model and observations (Sect. 3).

\subsection{Regional features}

The skill of the model to reproduce the main climatic features in all the regions displayed in Fig. 2 is analyzed in this section. Table 1 shows observed and modeled values of temperature, SLP and precipitation calculated as annual mean averaged over all stations contained in each area. In most of the regions, REMO temperature is higher than observed, being the extreme difference of $1.8^{\circ} \mathrm{C}$ in Western Argentina (WArg). Moreover, in Northern Andes (NA) and Patagonia (Ptg), temperature differences are almost negligible. REMO introduces an enhancement of ERA40 in the representation of annual mean temperature in regions NA, Tr, WAmz, NB and $\mathrm{NeB}$ where ERA40 exhibits negative biases. The differences of SLP REMO minus observed are for all regions between -2.7 and $1.6 \mathrm{hPa}$ and they are higher than $1 \mathrm{hPa}$ in only three 
Fig. 9 SLP REMO mean error (simulations minus observations)
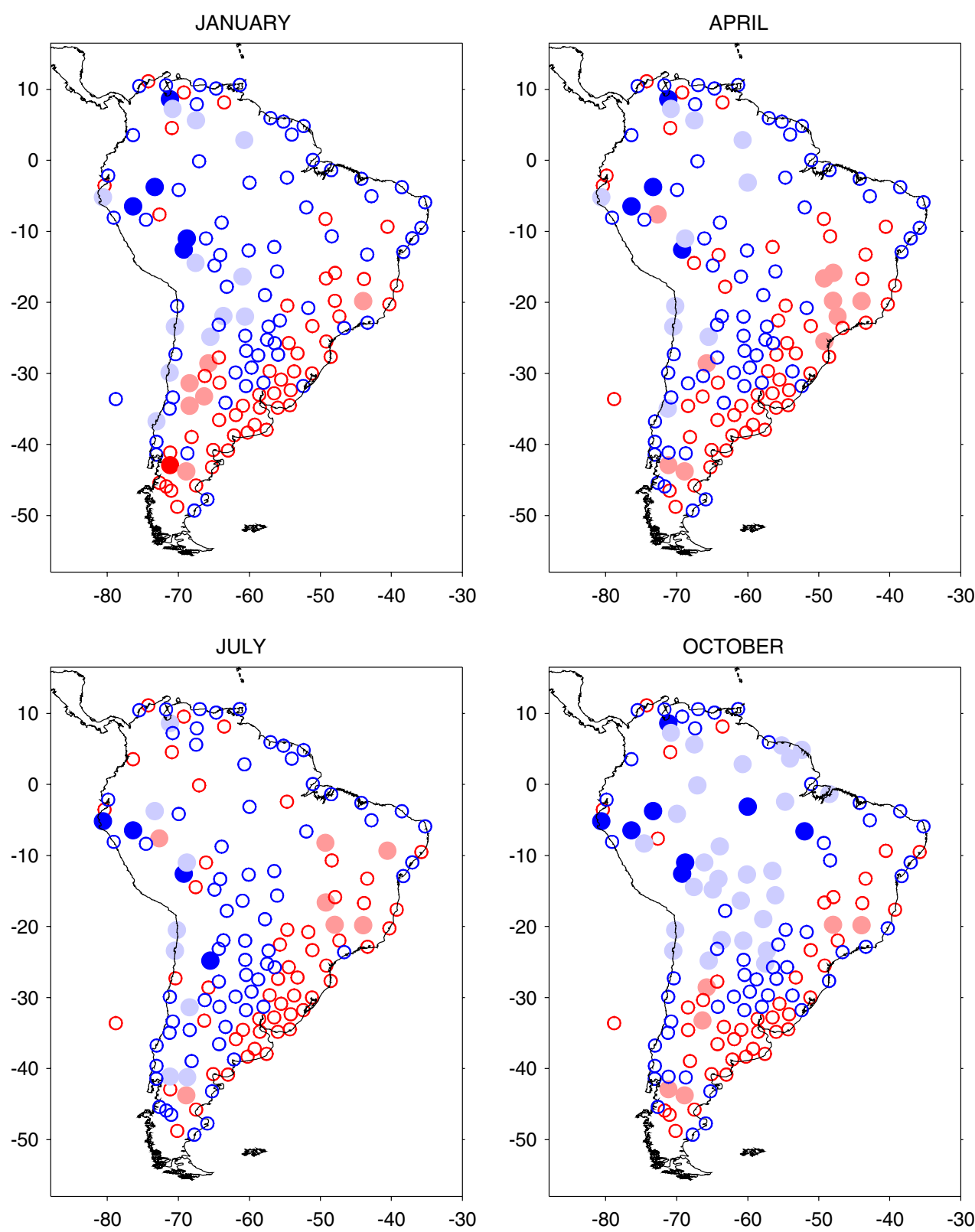

regions, Western Amazon (WAmz), Amazon (Amz) and eastern Brazil (EB). Regarding precipitation, values simulated by REMO are higher than observed for all regions. The lowest differences take place in Northern La Plata Basin (NLPB) and Pampa (Pm) regions (being lower than $15.5 \%$ ), while the highest difference is of $280.4 \%$ in NA. REMO introduces an enhancement of ERA40 in regions Tr, NB and WArg.

The annual cycles of temperature, SLP and precipitation for each region are shown in Fig. 10. These cycles show the performance of both REMO and ERA40 on monthly scales and the main comments are described below.

\subsubsection{Northern Andes (NA)}

Stations considered in this region are located along the coast of the Caribbean Sea as near to the Andes Mountains. The model reproduces throughout the year the nearly constant behavior of temperature and SLP with magnitudes not differing more than $1^{\circ} \mathrm{C}$ and $1 \mathrm{hPa}$ from the observed 
Table 1 Annual mean temperature, SLP and precipitation computed from observations (OBS), ERA40 and REMO, for each region described in the text

\begin{tabular}{|c|c|c|c|c|c|c|c|c|c|c|c|c|}
\hline \multirow[t]{2}{*}{ Region } & \multicolumn{4}{|l|}{$T$} & \multicolumn{4}{|l|}{ SLP } & \multicolumn{4}{|l|}{ PP } \\
\hline & OBS & ERA40 & REMO & $\Delta T$ & OBS & ERA40 & REMO & $\Delta \mathrm{SLP}$ & OBS & ERA40 & REMO & $\Delta \mathrm{PP}(\%)$ \\
\hline NA & 24.6 & 23.8 & 24.3 & -0.3 & $1,010.6$ & $1,011.4$ & $1,009.8$ & -0.8 & 102.3 & 290.0 & 389.2 & 280.4 \\
\hline $\operatorname{Tr}$ & 27.2 & 25.3 & 27.9 & 0.7 & $1,011.7$ & $1,012.3$ & $1,010.7$ & 1.0 & 116.5 & 182.1 & 170.4 & 46.3 \\
\hline WAmz & 25.9 & 23.9 & 26.9 & 1.0 & $1,012.1$ & $1,011.9$ & $1,009.4$ & -2.7 & 164.2 & 109.4 & 222.1 & 35.3 \\
\hline Amz & 26.7 & 25.3 & 27.9 & 1.2 & $1,010.4$ & $1,011.2$ & $1,009.3$ & 1.1 & 131 & 154.3 & 168 & 28.2 \\
\hline NB & 28.2 & 25.3 & 29.6 & 1.4 & $1,010.8$ & $1,011.4$ & $1,010.8$ & 0.0 & 99.8 & 217.6 & 157.3 & 57.6 \\
\hline $\mathrm{NeB}$ & 27.2 & 25.7 & 27.6 & 0.4 & $1,012.8$ & $1,012.5$ & $1,012.5$ & -0.3 & 91.7 & 135.0 & 161.4 & 76.0 \\
\hline EB & 23.2 & 22.8 & 23.6 & 0.4 & $1,013.2$ & $1,014.6$ & $1,014.8$ & 1.6 & 97.8 & 108.5 & 129.6 & 32.5 \\
\hline NLPB & 21.6 & 21.8 & 22.9 & 1.3 & $1,013.7$ & $1,013.9$ & $1,013.6$ & -0.1 & 108.6 & 98.9 & 118.7 & 9.3 \\
\hline $\mathrm{Pm}$ & 16.6 & 17.2 & 17.2 & 0.6 & $1,014.8$ & $1,014.8$ & $1,015.1$ & 0.3 & 76.5 & 67.7 & 88.3 & 15.4 \\
\hline WArg & 18.4 & 16.2 & 20.2 & 1.8 & $1,012.1$ & $1,013.4$ & $1,012.7$ & 0.6 & 46.0 & 79.8 & 69.3 & 50.6 \\
\hline Ptg & 13.2 & 12.3 & 13.1 & -0.1 & $1,011.4$ & $1,011.1$ & $1,011.8$ & 0.4 & 20.6 & 17.8 & 31.4 & 52.4 \\
\hline $\mathrm{SCh}$ & 10.7 & 10.2 & 11.4 & 0.7 & $1,015.2$ & $1,016.2$ & $1,014.4$ & -0.8 & 102.7 & 140.2 & 154.0 & 49.9 \\
\hline
\end{tabular}

Differences REMO minus OBS $(\Delta T, \Delta \mathrm{SLP}$ and $\Delta \mathrm{PP})$ are also shown. Units are: ${ }^{\circ} \mathrm{C}, \mathrm{hPa}, \mathrm{mm} \mathrm{month}^{-1}$. Differences of precipitation are presented in percentage regarding to the observed values

values. Nevertheless, it is notorious that the model simulates in this region much more rainfall than observed, probably due to a bad representation of the mean flow interaction with the orography (e.g., Solman et al. 2007).

\subsubsection{Tropical $(\mathrm{Tr})$}

Most of the stations are located at the Atlantic coast. The model reproduces the double maximum in the annual cycle of temperature although with the more intense warm peaks. Still differences between modeled and observed values are smaller than $1.5^{\circ} \mathrm{C}$ improving the ERA40 representation. The annual cycle of SLP is also well represented by the model although with values fairly lower than observed.

Though the model reproduces the structure of the annual march of rainfall, the intensity of the maximum that takes place between May and July is overestimated with differences of $60-70 \%$ from the observed values. While differences of rainfall in November and December are 60 and $120 \%$, respectively, in both January-April and August-October periods, they are lower than 35\%.

\subsubsection{Western Amazonia (WAmz)}

This region encloses stations located along the eastern slopes of the Andes where the topography does not overcome $300 \mathrm{~m}$ over the sea level. Temperature annual March is almost flat, a characteristic that the model is not able to reproduce. From April to June there are almost no differences between observed and REMO values but in August and September the modeled values exceed in $2-3^{\circ} \mathrm{C}$ the observed ones. On the other hand, the temperature annual cycle represented by ERA40 exhibits a considerable negative bias.

The model reproduces the annual cycle of SLP but with values lower than those observed, especially between August and October when the differences are of around $4 \mathrm{hPa}$. The two-maximum-like structure of the rainfall mean seasonal cycle is well simulated by the model but the simulated amplitude is much larger. While during the wet seasons simulated rainfalls are around 60-80\% higher than observed, during the dry period they are around 30-40\% lower than observed.

\subsubsection{Amazonia (Amz)}

From January to June there are no differences between observed and modeled temperature. But, as it was previously discussed in Sect. 4.1, a modeled excessive warming is found over this region during late winter and early spring, with differences of $5^{\circ} \mathrm{C}$ in August and September. A negative bias in the ERA40 representation is also evident as in WAmz.

Regarding the annual cycle of SLP, though the model reproduces both the winter maximum and the summer minimum, modeled values are smaller than the observed ones, especially between August and October when the differences are of almost $4 \mathrm{hPa}$.

As for WAmz, the model reproduces the main features of both the wet and dry seasons; although with a larger amplitude of the simulated seasonal cycle. The greatest 

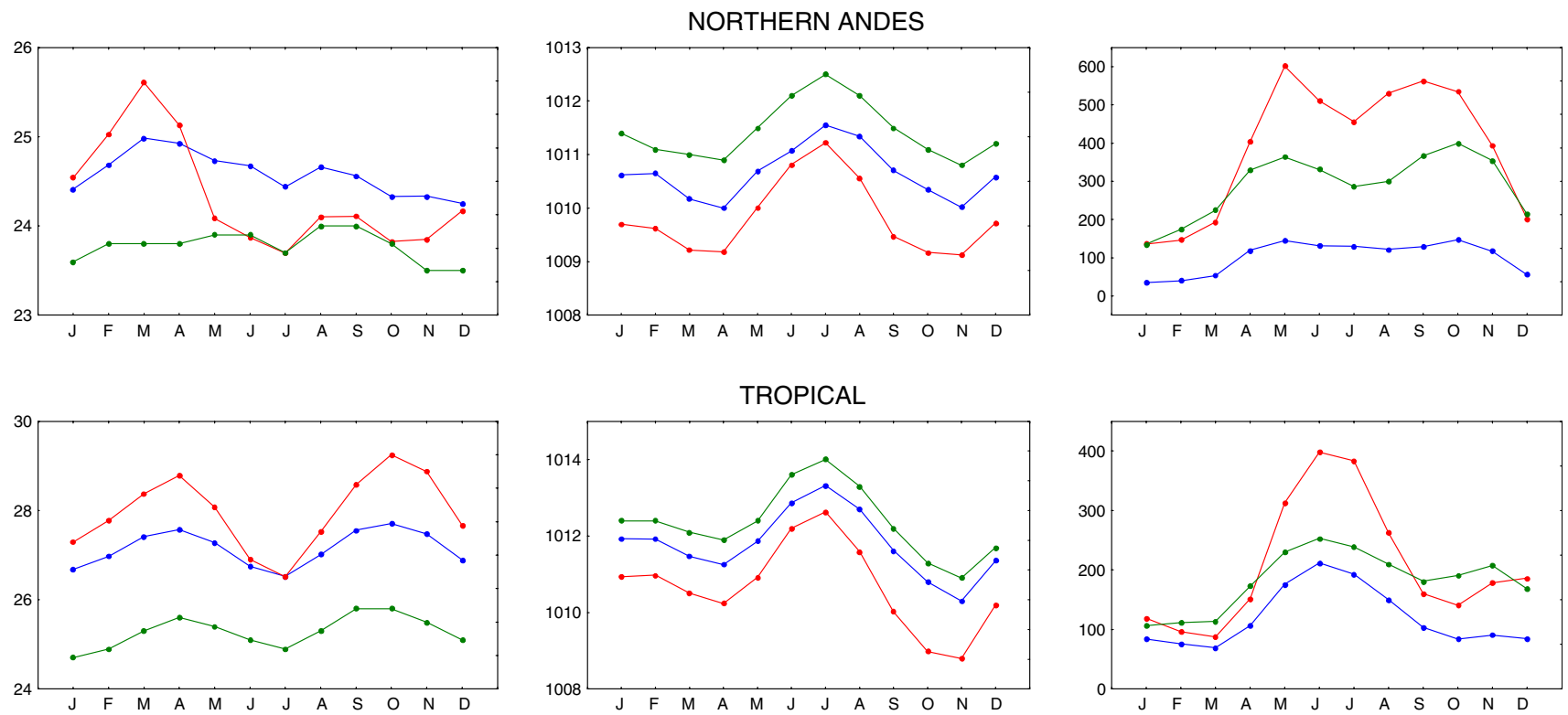

TROPICAL
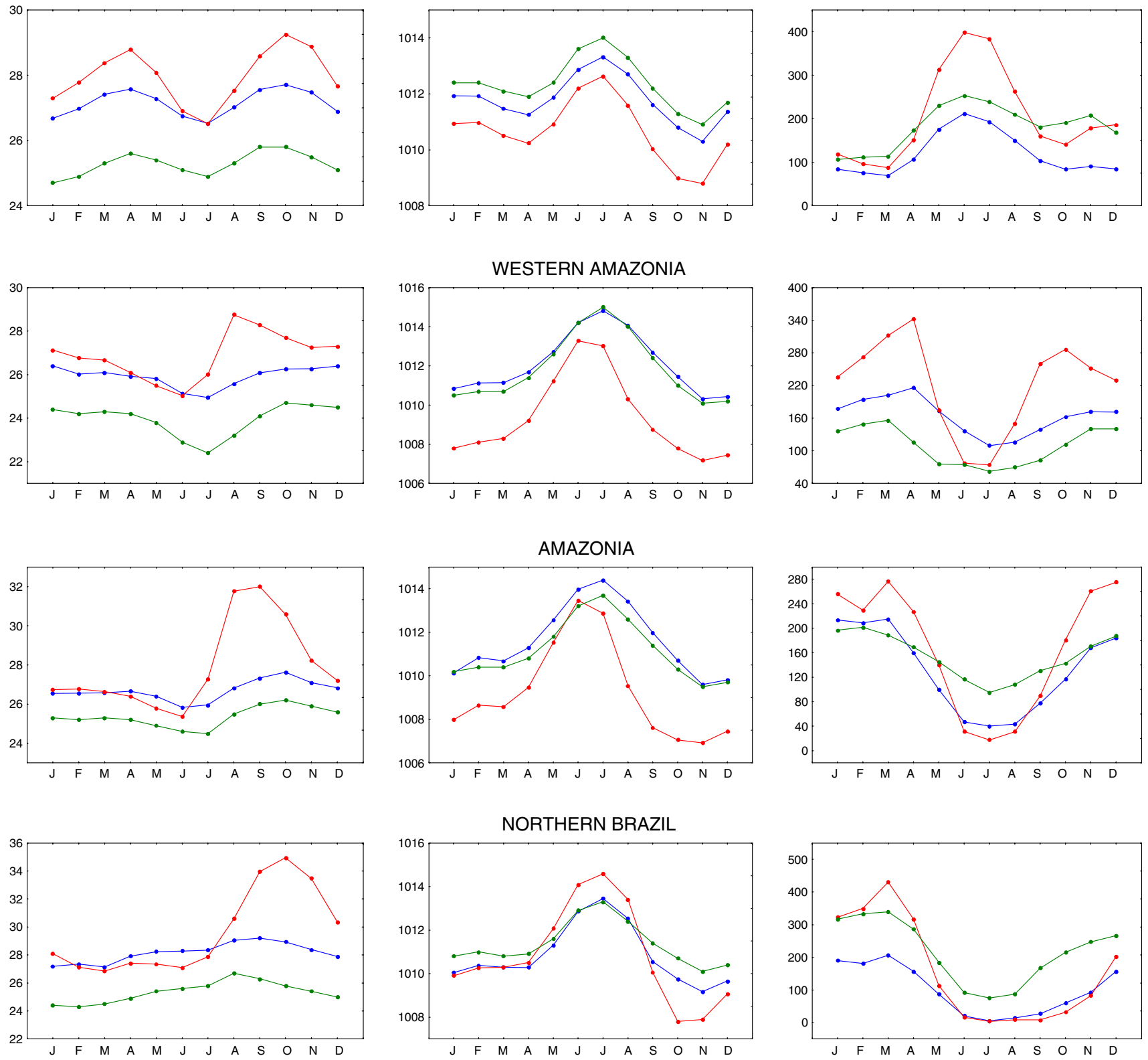

Fig. 10 Mean seasonal cycle from observations (blue), REMO (red) and ERA40 (green) of temperature (left), SLP (centre) and precipitation (right). Units are ${ }^{\circ} \mathrm{C}, \mathrm{hPa}, \mathrm{mm}$ month ${ }^{-1}$, respectively

discrepancies take place in October-December and in July when REMO precipitation is almost $60 \%$ higher and $55 \%$ lower than that observed, respectively. Nevertheless,
REMO introduces an enhancement of ERA40 in the representation of regional precipitation from June to September. 

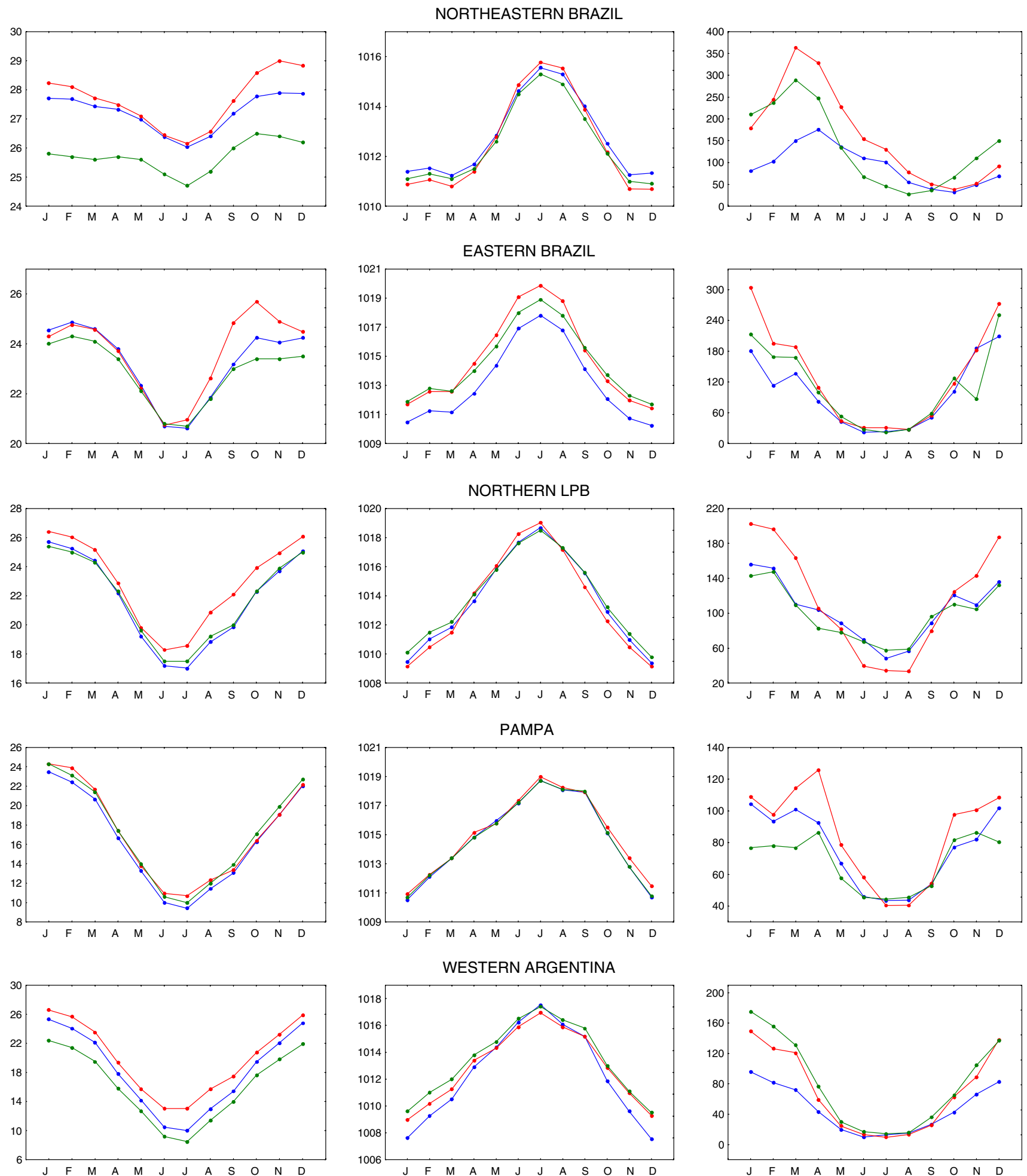

Fig. 10 continued

\subsubsection{Northern Brazil (NB)}

The temperature evolution for this region shows a simulated spring warming larger than observed, similarly to that found for the Amazon region (although delayed in 1 month). Moreover, while from September to November modeled temperatures are $5-6^{\circ} \mathrm{C}$ higher than those observed, from February to July differences are smaller and 

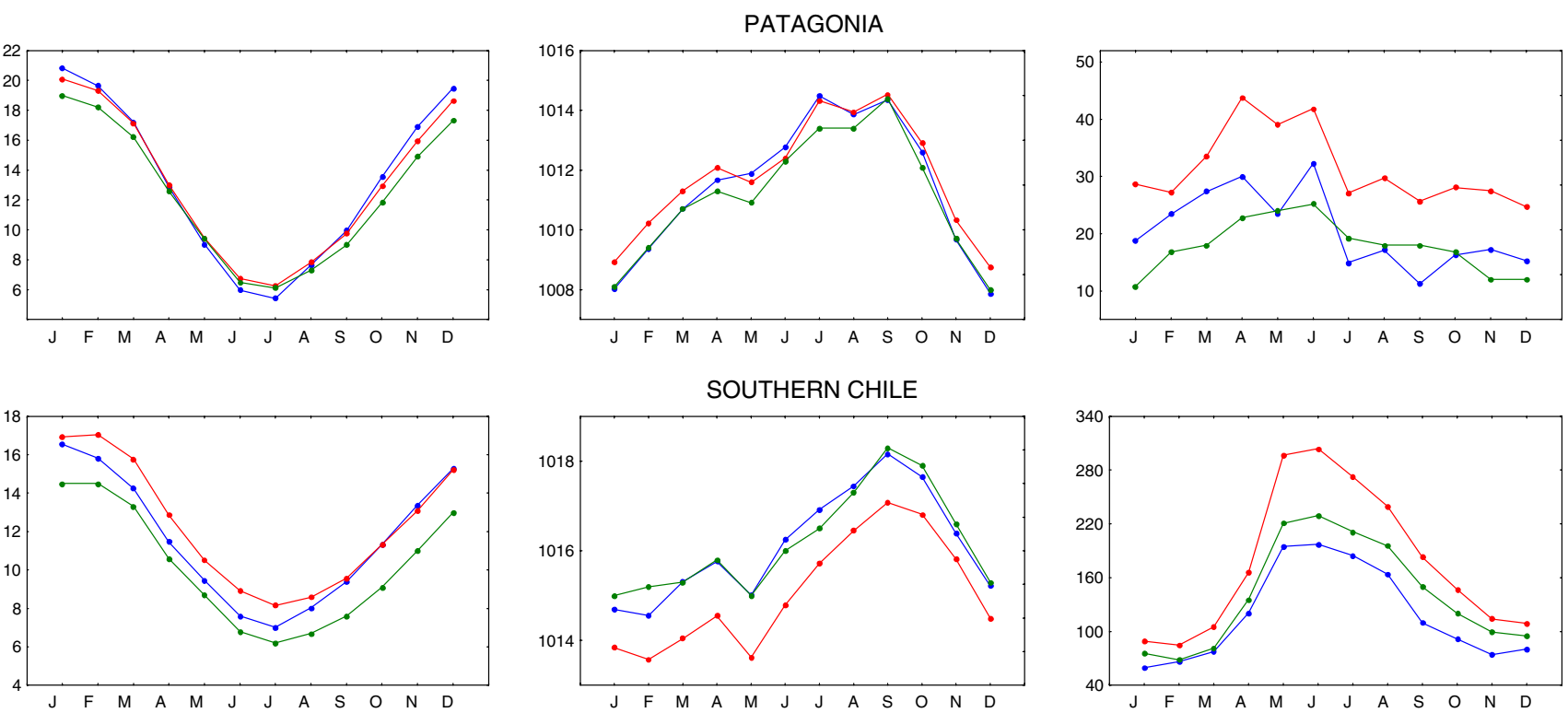

Fig. 10 continued

negative. Monthly mean temperature is represented by REMO better than ERA40 in the period January-July. The model reproduces the annual cycle of SLP with magnitudes differing in more than $1 \mathrm{hPa}$ only in October and November.

The precipitation annual cycle is represented by the model although with rainfall magnitudes associated with the wet season, extending from January to April, twice as large as those observed. On the contrary, from May to December, REMO makes an improvement of ERA40 in the representation of regional precipitation.

\subsubsection{Northeastern Brazil (NeB)}

Figure 2 shows that most of the stations included in this region are located along the Atlantic coast. The model has a good performance in representing the annual cycles of SLP and temperature, being for the latter clearly better than ERA40. Only during the dry season (October-December), modeled temperature differs in more than $0.5^{\circ} \mathrm{C}$ from the observations.

The model reproduces the yearly evolution of the rain better than ERA40, but with modeled precipitation always higher than the observed one, especially between January and March when the differences are 120-150\% with regard to the observed values.

\subsubsection{Eastern Brazil (EB)}

This region spreads over the northern sector of the Brazilian plateau (Fig. 1). The model reproduces monthly temperatures that differ in less of $0.8^{\circ} \mathrm{C}$ from those observed, excepting in September and October when the differences are of almost $1.5^{\circ} \mathrm{C}$. The annual cycle of SLP is well represented by the model with magnitudes of $1-2 \mathrm{hPa}$ higher than the observed ones. Furthermore, REMO is able to capture the summer rainy (winter dry) season. Nevertheless, as it was found for the other tropical regions, the simulated precipitation peak is almost $60 \%$ higher with regard to the observed values.

\subsubsection{Northern La Plata basin (NLPB)}

This region covers most of northern La Plata basin (Berbery and Barros 2002). Modeled temperatures are higher than the observed values for all months with differences of almost $2^{\circ} \mathrm{C}$ in August and September. There is a good representation of the annual cycle of SLP with differences lower than $0.6 \mathrm{hPa}$ in all months except in September when the difference is $0.9 \mathrm{hPa}$.

The model reproduces the rainy summer and dry winter that characterize the region, although they are around 30$40 \%$ drier and wetter than observed.

\subsubsection{Pampa (Pm)}

This region spreads almost totally along the flat territory usually known as the Pampas prairie (Fig. 1). There is a good agreement between observed and modeled temperature annual cycle, with differences between simulated and observed values no larger than $1{ }^{\circ} \mathrm{C}$. REMO well reproduces the SLP annual cycle with differences lower than $1 \mathrm{hPa}$ in all months (from January to October differences are lower than $0.5 \mathrm{hPa}$ ). The annual cycle of precipitation 
is also well described by the model; even the magnitudes are similar to the observed values because in 6 months differences are lower than $10 \%$ and the maximum difference is $30 \%$ in April.

\subsubsection{Western Argentina (WArg)}

The territory on which this region spreads is a transition between the plains and the Andes Mountains. The model reproduces accurately the seasonal cycle of the temperature although simulated values are higher than the observed ones all year long. The annual cycle of SLP is well represented by the model with magnitudes that differ only in December $1.5 \mathrm{hPa}$ from observations.

Both the rainy summer and dry winter seasons are well reproduced by the model. Magnitude differences are smaller than $35 \%$ from April to November, while in the rest of the year they are larger (between 48 and 70\%).

\subsubsection{Patagonia (Ptg)}

In summer (winter), modeled temperature values are lower (higher) than the observed ones. Still differences are in general smaller than $0.5^{\circ} \mathrm{C}$. The annual cycle of SLP is well reproduced by the model with values that differ less than $1 \mathrm{hPa}$ with the reality. An overestimation of precipitation is evident all year round, with differences of more than $70 \%$ to the observations from July to October.

\subsubsection{Southern Chile (SCh)}

Stations in this region are located on the coast of south Pacific near the Andes. From September to January the differences between observed and modeled temperature values are smaller than $0.4^{\circ} \mathrm{C}$. In the rest of the year, modeled temperatures are $1-1.5^{\circ} \mathrm{C}$ higher than the observed ones. Over this extratropical region, REMO makes an enhancement of ERA40 in the representation of temperature from August to February.

The model captures the annual cycle of SLP but with values lower than the observed ones (with differences between 0.5 and $1.5 \mathrm{hPa}$ ). Though the model reproduces the annual cycle of rainfall characterized by maximum in winter and minimum in summer, there is an overestimation of the magnitudes. Differences are between 30\% (in February) and $70 \%$ (in September). From May to August the modeled precipitation is $45-55 \%$ higher than the observed one.

\section{Summary and conclusions}

The ability of the REMO model in reproducing the South American climate was analyzed using an atmospheric hindcast generated by means of dynamical downscaling from the ECMWF-ERA40 reanalysis. Time series of temperature, sea level pressure and precipitation were compared to observed and reanalyzed values at stations distributed along South America. Wind fields at low and upper levels from ECMWF-ERA40 and REMO were also compared.

In general, it was found that the model is able to reproduce the basic structure of the low-level circulation in South America, particularly the features that characterize the summer monsoon circulation, with some deficiencies in reproducing the South American Low-Level Jet structure. At upper levels the main summer circulation features like the Bolivian High and the associated subtropical jet are well located in the simulations, although with larger magnitudes than that displayed by ERA40. Sea-level pressure fields are in general well represented by the model, with the exception of the Amazon and central Andes regions where the differences compared to observations are larger than $2 \mathrm{hPa}$.

Regarding precipitation, the model exhibits reasonable skill in representing the general features of the mean seasonal cycle of precipitation over South America. In particular during summer, the model well simulates the SACZ, although it overestimates precipitation in both tropical and subtropical regions. Moreover, temperature differences between observations and simulations are in general smaller than $1.5^{\circ} \mathrm{C}$ over most of the continent, except during spring when those differences are quite large (around $5^{\circ} \mathrm{C}$ ) particularly over the Amazon and northern Brazil regions.

Results show that the dynamical downscaling performed using REMO introduces a regional enhancement of the global reanalysis in precipitation and temperature in some regions of South America. Specifically, precipitation over $25^{\circ} \mathrm{S}-40^{\circ} \mathrm{S}$ in summer and over most of the region between $0^{\circ}$ and $40^{\circ} \mathrm{S}$ in winter as well as the surface temperature conditions at the tropical regions in the warm season are better represented by this downscaling than by the reanalysis. Nevertheless, the model exhibits some deficiencies to outperform the reanalysis during the whole annual cycle.

These results confirm that the REMO model might be a useful tool for regional downscaling of global simulations of present and future climates. Although, a further analysis will be done in future works in order to identify the causes of the model deficiencies, particularly the biases observed over the Amazon, northern and eastern Brazil in temperature and precipitation. Many studies have linked delayed onset of the rainy season in the Amazon to soil moisture (e.g., Fu et al. 1999; Fu and $\mathrm{Li}$ 2004; $\mathrm{Li}$ and $\mathrm{Fu}$ 2004). Nevertheless, the processes related with model biases over eastern Brazil and the SACZ regions are not clear yet. Therefore, the ability of the model in representing the processes controlling temperature and precipitation 
conditions over those particular tropical regions, like moisture convergence and soil moisture-atmosphere feedback, should be studied in detail. Finally, predictability and downscaling issues over South America will be also explored in future works, nesting REMO with GCM simulations.

Acknowledgments This research was supported by UBA X264, ANPCyT/PICT-2004 25269, CONICET/PIP-5400 and CLARIS (EU Project 001454). ERA40 data used in this study have been provided by ECMWF and have been obtained from the IPSL Data Server. Comments and suggestions provided by two anonymous reviewers were very helpful in improving this paper.

Open Access This article is distributed under the terms of the Creative Commons Attribution Noncommercial License which permits any noncommercial use, distribution, and reproduction in any medium, provided the original author(s) and source are credited.

\section{References}

Aldrian E, Dumenil-Gates L, Jacob D, Podzun R, Gunawan D (2004) Long-term simulation of Indonesian rainfall with the MPI regional model. Clim Dyn 22:795-814. doi: 10.1007/s00382-004-0418-9

Berbery E, Barros V (2002) The hydrologic cycle of the La Plata basin in South America. J Hydrometeorol 3:630-645

Berbery E, Collini E (2000) Springtime precipitation and water vapor flux over southeastern South America. Mon Weather Rev 128:1328-1346

Birnbaum G (2003) Simulation of the atmospheric circulation in the Weddell Sea region using the limited-area model REMO. Theor Appl Climatol 74:255-271. doi:10.1007/s00704-002-0680-x

Chen T-C, Weng S, Schubert S (1999) Maintenance of austral summertime upper-tropospheric circulation over tropical South America: the Bolivian high-Nordeste low systems. J Atmos Sci 56:2081-2100

Collins W, Bitz C, Blackmon M, Bonan G, Bretherton CS, Carton J, Chang P, Doney S, Hack J, Henderson T, Kiehl J, Large W, Mckenna D, Santer B, Smith R (2006) The community climate system model version 3 (CCSM3). J Clim 19:2122-2143

Dai A (2006) Precipitation characteristics in eighteen coupled climate models. J Clim 19:4605-4630. doi:10.1175/JCLI3884.1

Davies H (1976) A lateral boundary formulation for multi-level prediction models. Q J Roy Meteor Soc 102:405-418

Dümenil L, Todini E (1992) A rainfall-runoff scheme for use in the Hamburg climate model. Advances in Theoretical Hydrology. In: O'Kane J (ed.) European Geophysical Society Series on Hydrological Sciences, 1, Elsevier Amsterdam, pp 129-157

Fu R, Li W (2004) The influence of the land surface on the transition from dry to wet season in Amazonia. Theor Appl Climatol 78:97-110

Fu R, Zhu B, Dickinson R (1999) How do atmosphere and land surface influence seasonal changes of convection in the tropical Amazon? J Clim 12:1306-1321

Gandú A, Silva Días P (1998) Impact of tropical heat sources on the South American tropospheric circulation and subsidence. J Geophys Res 103 (D6): 6001-6015

Giorgi F, Bi X, Pal J (2004) Mean, interannual variability and trends in a regional climate change experiment over Europe. I. Presentday climate (1961-1990). Clim Dyn 22:733-756. doi: 10.1007/s00382-004-0409-x
Hoffmann J (1975) Maps of mean temperature and precipitation. Climatic atlas of South America, vol 1. WMO. UNESCO, pp 128

Jacob D (2001) A note to the simulation of the annual and interannual variability of the water budget over the Baltic Sea drainage basin. Meteorol Atmos Phys 77:61-73

Jacob D, Andrae U, Elgered G, Fortelius C, Graham L, Jackson S, Karstens U, Koepken C, Lindau R, Podzun R, Rockel B, Rubel F, Sass H, Smith R, Van den Hurk B, Yang X (2001) A comprehensive model intercomparison study investigating the water budget during the BALTEX-PIDCAP period. Meteor Atmos Phys 77:19-43

Jacob D, Bärring L, Christensen O, Christensen J, de Castro M, Déqué M, Giorgi F, Hagemann S, Hirschi M, Jones R, Kjellström E, Lenderink G, Rockel B, Sánchez E, Chr Schär, Seneviratne S, Somot S, van Ulden A, van den Hurk B (2007) An inter-comparison of regional climate models for Europe: model performance in present-day climate. Clim Change 81:3152. doi:10.1007/s10584-006-9213-4

Kjellström E, Bärring L, Jacob D, Jones R, Lenderink G, Schär C (2007) Modelling daily temperature extremes: recent climate and future changes over Europe. Clim Change 81:249-265. doi: 10.1007/s10584-006-9220-5

Kodama Y (1992) Large-scale common features of subtropical precipitation zones (the Baiu frontal zone, the SPCZ and SACZ). I. Characteristics of subtropical frontal zones. J Meteor Soc Jpn 70:813-836

Lenters J, Cook K (1995) Simulation and diagnosis of the regional summertime precipitation climatology of South America. J Clim 8:2988-3005

Lenters J, Cook K (1997) On the origin of the Bolivian high and related circulation features of the South American climate. J Atmos Sci 54(5):656-677

Li W, Fu R (2004) Transition of the large-scale atmospheric and land surface conditions from the dry to the wet season over Amazonia as diagnosed by the ECMWF Re-Analysis. J Clim 17:2637-2651

Misra V, Dirmeyer P, Kirtman B (2003) Dynamic downscaling of seasonal simulations over South America. J Clim 16:103-117

Nogués-Paegle J, Mo K (1997) Alternating wet and dry conditions over South America during summer. Mon Weather Rev 125:279-291

Nordeng T (1994) Extended versions of the convective parametrization scheme at ECMWF and their impact on the mean and transient activity of the model in the tropics. ECMWF Research Department, Technical Memorandum No. 206, October 1994, $41 \mathrm{pp}$, European Centre for Medium Range Weather Forecasts, Reading, UK.

Prohaska F (1976) Climates of Central and South America. World Survey of Climatology. In: Schwerdtfeger (ed). Elsevier, Amsterdam, pp 13-72

Randall D, Wood R, Bony S, Colman R, Fichefet T, Fyfe J, Kattsov V, Pitman A, Shukla J, Srinivasan J, Stouffer R, Sumi A, Taylor K (2007) Climate models and their evaluation. Contribution of Working Group I to the Fourth Assessment Report of the Intergovernmental Panel on Climate Change. In: Solomon S, Qin D, Manning M, Chen Z, Marquis M, Averyt K, Tignor M, Miller $\mathrm{H}$ (eds). Cambridge University Press, Cambridge, United Kingdom and New York, NY, USA.

Rojas M, Seth A (2003) Simulation and sensitivity in a nested modeling system for South America. Part II: GCM boundary forcing. J Clim 16:2454-2471

Seth A, Rojas M (2003) Simulation and sensitivity in a nested modeling system for South America. Part I: Reanalyses boundary forcing. J Clim 16:2437-2453

Seth A, Rojas M, Liebmann B, Qian J-H (2004) Daily rainfall analysis for South America from a regional climate model and 
station observations. Geophys Res Lett 31:L07213. doi: 10.1029/2003GL019220

Seth A, Rauscher S, Camargo S, Qian J-H, Pal J (2007) RegCM3 regional climatologies for South America using reanalysis and ECHAM global model driving fields. Clim Dyn. doi: 10.1007/s00382-006-0191-z

Solman S, Nuñez M, Cabre M (2007) Regional climate change experiments over southern South America. I: Present climate. Clim Dyn. doi 10.1007/s00382-007-0304-3

Sotillo M, Ratsimandresy A, Carretero J, Bentamy A, Valero F, González-Rouco F (2005) A high-resolution 44-year atmospheric hindcast for the Mediterranean Basin: contribution to the regional improvement of global reanalysis. Clim Dyn 25:219 236. doi:10.1007/s00382-005-0030-7

Tiedtke M (1989) A comprehensive mass flux scheme for cumulus parameterization in large scale models. Mon Weather Rev 117:1779-1800

Vera C, Higgins W, Amador J, Ambrizzi T, Garreaud R, Gochis D, Gutzler D, Lettenmaier D, Marengo J, Mechoso C, Nogues-
Paegle J, Silva Dias P, Zhangi C (2006a) Toward a unified view of the American monsoon systems. J Clim 19:4977-5000

Vera C, Baez J, Douglas M, Emmanuel C, Marengo J, Meitin J, Nicolini M, Nogues-Paegle J, Paegle J, Penalba O, Salio P, Saulo C, Silva Dias M, Silva Dias P, Zipser E (2006b) The South American Low-Level Jet experiment. Bull Amer Meteor Soc 87(1): 63-77 doi: 10.1175/BAMS-87-1-63

Virji H (1981) A preliminary study of summertime tropospheric circulation patterns over South America estimated from cloud winds. Mon Weather Rev 109:599-610

Wang M, Paegle J (1996) Impact of analysis uncertainty upon regional atmospheric moisture flux. J Geophys Res 101:72917303

Xie P, Arkin P (1997) Global precipitation: a 17-year monthly analysis based on gauge observations, satellite estimates, and numerical model outputs. Bull Am Meteor Soc 78:2539-2558

Zhou J, Lau K (1998) Does a monsoon climate exist over South America? J Clim 11:1020-1040 